This Accepted Author Manuscript is copyrighted and published by Elsevier. It is posted here by agreement between Elsevier and University of Brasilia. Changes resulting from the publishing process - such as editing, corrections, structural formatting, and other quality control mechanisms - may not be reflected in this version of the text. The definitive version of the text was subsequently published in [International Journal of Insect Morphology and Embryology, Volume 23, Issue 1, January 1994, Pages 57-67, doi:10.1016/0020-7322(94)90015-9].You may download, copy and otherwise use the AAM for non-commercial purposes provided that your license is limited by the following restrictions:

(1) You may use this AAM for non-commercial purposes only under the terms of the CC-BY-NCND license.

(2) The integrity of the work and identification of the author, copyright owner, and publisher must be preserved in any copy.

(3) You must attribute this AAM in the following format: [agreed attribution language, including link to CC BY-NC-ND license + Digital Object Identifier link to the published journal article on Elsevier's ScienceDirect ${ }^{\circledR}$ platform].

Este Manuscrito do Autor Aceito para Publicação (AAM) é protegido por direitos autorais e publicado pela Elsevier. Ele esta disponível neste Repositório, por acordo entre a Elsevier e a Universidade de Brasília. As alterações decorrentes do processo de publicação - como a edição, correção, formatação estrutural, e outros mecanismos de controle de qualidade - não estão refletidas nesta versão do texto. A versão definitiva do texto foi posteriormente publicado em [International Journal of Insect Morphology and Embryology, Volume 23, Número 1, Janeiro de 1994, Páginas 57-67, doi:10.1016/0020-7322(94)90015-9]. Você pode baixar, copiar e utilizar de outra forma o AAM para fins não comerciais, desde que sua licença seja limitada pelas seguintes restrições:

(1) Você pode usar este AAM para fins não comerciais apenas sob os termos da licença CC- BYNC-ND.

(2) A integridade do trabalho e identificação do autor, detentor dos direitos autorais e editor deve ser preservado em qualquer cópia.

(3) Tem de atribuir este AAM no seguinte formato: [acordo na linguagem atribuída, incluindo o link para CC BY-NC-ND licença Digital + DOI do artigo publicado na revista Elsevier ScienceDirect ${ }^{\circledR}$ da plataforma]. 


\title{
Cytochemical localization of enzymes in the spermatid and the spermatozoon of Culex quinquefasciatus say (Diptera : Culicidae)
}

Sonia N. Bao

Wanderley De Souza

\begin{abstract}
Ultrastructural cytochemical techniques were used for the localization of phosphatases in spermatid and spermatozoon of the mosquito, Culex quinquefasciatus (Diptera : Culicidae). Acid phosphatase was found mainly in the trans-most portion of the Golgi complex. Thiamine pyrophosphotase was preferentially located in the cis-most portion of the Golgi complex. Glucose-6-phosphatase was located in the endoplasmic reticulum and cisternae of the transition zone between the endoplasmic reticulum and the Golgi complex. The complex membrane of the anterior acrosomal region and the axoneme showed acid phosphatase activity. Reaction products indicating the presence of acid phosphatase, thiamine pyrophosphatase, and glucose-6-phosphatase, were observed on the spermatozoon surface at the head and tail regions. These observations support the idea that various phosphatases may play some role in spermatid differentiation.
\end{abstract}

Keywords: Acid phosphatase; thiamine pyrophosphatase; glucose-6-phosphatase; electron microscopy

\section{INTRODUCTION}

The SPERMATOZOON is a highly specialized cell, which results from a complex process of cell differentiation, during which morphological, biochemical, and physiological changes take place (for reviews, see Phillips, 1970; Baccetti, 1972; Fawcett, 1975; Baccetti and Afzelius, 1976). The typical insect spermatozoon is an extremely thin and elongated cell showing a nucleus with highly condensed chromatin, an acrosome rich in hydrolases, and a tail which contains mitochondrial derivatives and axoneme. During spermiogenesis, parts of the nuclear and cytoplasmic contents, including some organelles, are eliminated, and changes occur in the plasma membrane. This phenomenon involves the participation of several enzymes, including the phosphatases. The hydrolases, and particularly acid phosphatase, play a role in the process of spermatid maturation. Previous studies have localized this enzyme in the proacrosomal vesicles (Anderson, 1968; Souza et al., 1988; Thorne-Tjomsland et al., 1988; Bao et al., 1989) and the axoneme (Anderson et al., 1968; Bigliardi et al., 1970; Baccetti et al., 1971; Beaulaton and Perrin-Waldemar, 1973, Bao and Dolder, 1990; Bao, 1991). ATPases have been found as integral components of the membrane in the head region of the sperm (Gordon, 1973), and in the axoneme (Anderson and Personne, 1970; Baccetti et al., 1973a, b; Yasuzumi et al., 1973; Cibert, 1985; Curtis et al., 1989). Thiamine pyrophosphatase activity has been detected in the plasma membranes of insect (Baccetti, 1977) and mollusc (Anderson et al., 1968) sperm cells. In addition, glucose-6-phosphatase activity has been shown in the endoplasmic reticulum and 
Golgi complex of rat spermatocyes and spermatids (Thorne-Tjomsland et al., 1991), and in the axonemal and mitochondrial compartments of spermatozoa of some invertebrate and vertebrate species (Anderson and Personne, 1970; Bigliardi et al., 1970). The aim of the present study is to analyse the localizations of acid phosphatase, thiamine pyrophosphatase, and glucose-6-phosphatase during spermiogenesis in Culex quinquefasciatus. This study allowed us to obtain new information on the involvement of its enzyme in the structural and physiological transformations of the spermatids, with the appearance of particular structures, such as the acrosome and the axoneme, as well as plasma membrane remodelling.]

\section{MATERIALS AND METHODS}

The insects were obtained from a colony maintained in the Department of Entomology of the Instituto Oswaldo Cruz, Rio de Janeiro, RJ, Brasil. The testes and seminal vesicles were dissected and briefly fixed for $15 \mathrm{~min}$ at $4^{\circ} \mathrm{C}$ in $1 \%$ glutaraldehyde buffered with $0.1 \mathrm{M}$ cacodylate buffer, pH 7.2. After fixation, the specimens were washed with buffer and used for the cytochemical experiments.

\section{Enzyme cytochemistrv}

Acid phosphatase activity. The fixed-washed testes and seminal vesicles were incubated for $1 \mathrm{hr}$ at $37^{\circ} \mathrm{C}$ in the following medium: $0.1 \mathrm{M}$ Tris-maleate buffer, $\mathrm{pH}$ 5.0, $10 \mathrm{mM}$ sodium B-glycerophosphate, $2 \mathrm{mM}$ cerium chloride and 5\% sucrose (Robinson and Karnovsky, 1983). In some cases, the specimens were incubated for $45 \mathrm{~min}$ at $37^{\circ} \mathrm{C}$ in a medium containing $7 \mathrm{mM}$ cytidine-5-monophosphate, $2 \mathrm{mM}$ cerium chloride and $5 \%$ sucrose in $0.1 \mathrm{M}$ Tris-maleate buffer, pH 5.0 (Pino et al., 1981). For controls either (a) the substrate was omitted or (b) $10 \mathrm{mM}$ sodium fluoride was added to the complete incubation medium.

Thiamine pyrophosphatase activity. The fixed-washed testes and seminal vesicles were incubated for $1 \mathrm{hr}$ at $37^{\circ} \mathrm{C}$ in medium containing: $2.2 \mathrm{mM}$ thiamine pyrophosphate, $5 \mathrm{mM}$ manganese chloride, $4 \mathrm{mM}$ cerium chloride, $5 \%$ sucrose and $0.1 \mathrm{M}$ Tris-maleate buffer, $\mathrm{pH} 7.2$ (Angermuller and Fahimi, 1984). The controls were incubated in the same medium from which the substrate was omitted.

Glucose-6-phosphatase activity. The fixed-washed testes and seminal vesicles were incubated for $1 \mathrm{hr}$ at $37^{\circ} \mathrm{C}$ in a medium containing: $5 \mathrm{mM}$ glucose-6-phosphate, $5 \mathrm{mM}$ manganese chloride, $4 \mathrm{mM}$ cerium chloride, $5 \%$ sucrose and $0.1 \mathrm{M}$ Tris-maleate buffer, pH 6.5 (Robinson and Karnovsky, 1983). The controls were incubated in the same medium from which 
the substrate was omitted. After incubation of the testes and seminal vesicles in one of the media as described above, the specimens were washed with cacodylate buffer and fixed again for $3 \mathrm{hr}$ at $4^{\circ} \mathrm{C}$ in a solution containing $4 \%$ paraformaldehyde, $2 \%$ glutaraldehyde in $0.1 \mathrm{M}$ cacodylate buffer, $\mathrm{pH}$ 7.2. Then, the specimens were washed in clean buffer, and postfixed in a solution containing $1 \%$ osmium tetroxide, $0.8 \%$ potassium ferricyanide and $5 \mathrm{mM}$ calcium chloride in $0.1 \mathrm{M}$ cacodylate buffer. Subsequently, they were dehydrated in acetone and embedded in Epon. Thin sections were stained with uranyl acetate and lead citrate, and examined in a JEOL JEM $100 \mathrm{C}$ transmission electron microscope.

\section{RESULTS}

The general structure of the spermatids in C. quinquefasciatus by transmission electron microscopy has been described in detail previously (Bao and de Souza, 1993). The spermatids undergo a series of modifications, resulting in the formation of a highly differentiated cell, the spermatozoon, which consists of 2 anatomically and functionally distinct regions. An elongated rod-like head, contains the nucleus and the acrosome, and the tail, which is formed by an axoneme and 2 mitochondrial derivatives containing a crystalline matrix (Bao et al., 1992). The sperm plasma membrane is asymmetric, with its outer surface slightly thickened by an overlying coat, a structure which is formed during the spermatid differentiation process (Bao and de Souza, 1992, 1993).

The spermatids showed phosphatase activity in various structures during their differentiation. 


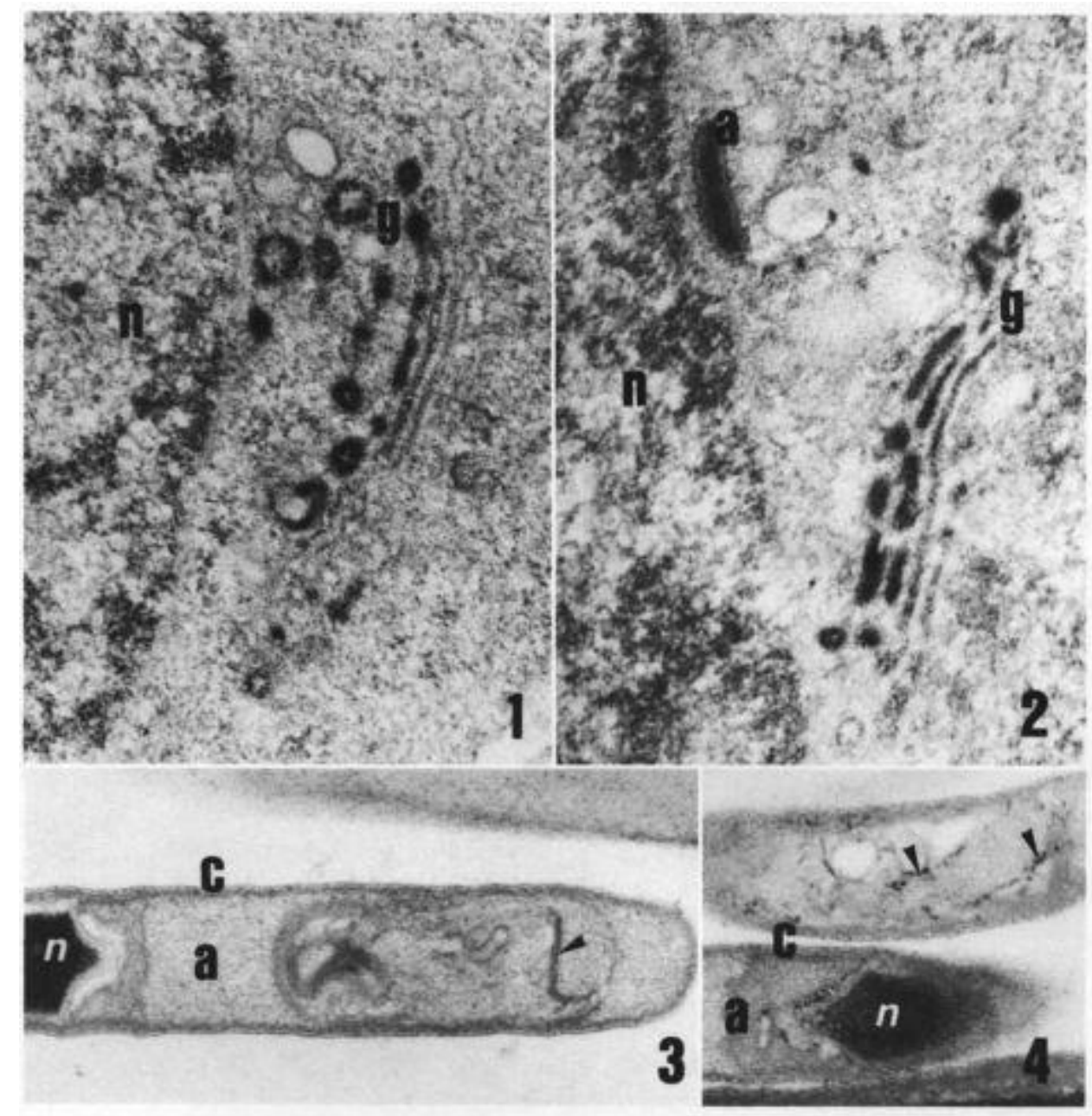

FIGS 1-4. Localization of acid phosphatase in spermatids and spermatozoa. F Gs 1, 2. Thin sections of spermatids incubated in a medium containing cytidine-5-monophosphate. Reaction product is seen mainly in cisternae located in trans region of Golgi complex (g). $a=$ acrosome; $n=$ nucleus. Figure 1: $x$ 54,000; Fig. 2: $x$ 74,700. FIGS 3, 4. Thin sections of spermatozoa incubated in a medium containing cytidine-5-monophosphate (Fig. 3) or B-glycerophosphate (Fig. 4). Longitudinal sections through spermatozoa head. A light labelling is observed in membrane complex (arrowhead) of anterior acrosomal region, $a=$ acrosome; $c=$ coat; $n=$ nucleus. Figure 3: x 45,000; Fig. 4: x 54,000. FIGS 5-9. Localization of acid phosphatase in spermatids and spermatozoon.

\section{Acid phosphatase activity}

Incubation of the early spermatids in a medium containing either B-glycerophosphate or cytidine-5-monophosphate as substrate, and cerium as capture agent, led to the appearance of an electron-dense reaction product, indicating the presence of acid phosphatase activity. The reaction product was seen in association with several cisternae of the Golgi complex, but mainly with those in the trans-most region (Figs 1, 2). However, no reaction product was observed in the acrosome, although it has been shown that the Golgi complex participates actively in the formation of the acrosome (Fig. 2). Occasionally, a light 
labelling was observed in the membrane complex of the anterior acrosomal region (Figs 3, 4). The Golgi complex also seems to be involved in the changes that occur in the flagellum (Fig. 5).

Intense deposition of reaction product was localized specifically in the spermatozoon axoneme, particularly in the electron-dense fibres or radial spokes that extend from the central rod towards the 9 microtubule doublets, as well as in the electron-dense fibres connecting the accessory microtubules (Figs 6,7 ). The intensity of reaction varied from one axoneme to another and also among the dense fibres of a single axoneme (Fig. 6). A diffuse weak reaction was observed in the paracrystalline matrix of some mitochondrial derivatives (Fig. 8).

Reaction product was uniformly distributed over the entire spermatozoon surface. In some cells, however, labelling was not very intense (Figs 6, 7). Omission of the substrate or addition of sodium fluoride to the incubation medium abolished the appearance of the reaction product (Fig. 9).

\section{Thiamine pyrophosphatase activity.}

After incubating the spermatids in a medium, containing thiamine pyrophosphate as substrate, and cerium as capture agent, we found deposits of reaction product in several cisternae of the Golgi complex (Figs 10, 11). Deposition was more evident at the cis region (Fig. 11). Generally, the reacting cisternae displayed heavy, uniformly distributed deposition.

Reaction product, indicative of thiamine pyrophosphatase, was seen in the layer of amorphous material that surrounded the paracrystalline structure of the mitochondrial derivatives of spermatids (Fig. 12).

Intense reaction for thiamine pyrophosphatase was also observed in the spermatozoon surface coat, both in the head and tail regions (Figs 13, 14).

\section{Glucose-6-phosphatase activity}

Following incubation of the spermatids in a medium containing glucose-6-phosphate as substrate and cerium chloride as capture agent, reaction product was seen in association with the endoplasmic reticulum (Fig. 15). In some cells, the reaction product was observed in cisternae located in the transition zone between the endoplasmic reticulum and the Golgi complex (Fig. 16). In several spermatids the cisternae that surround the axoneme were also stained (Fig. 17). Electron-dense reaction production was observed in the spermatozoon surface coat (not shown). 
In all cases, omission of the substrates from the incubation medium abolished the appearance of reaction product (not shown).

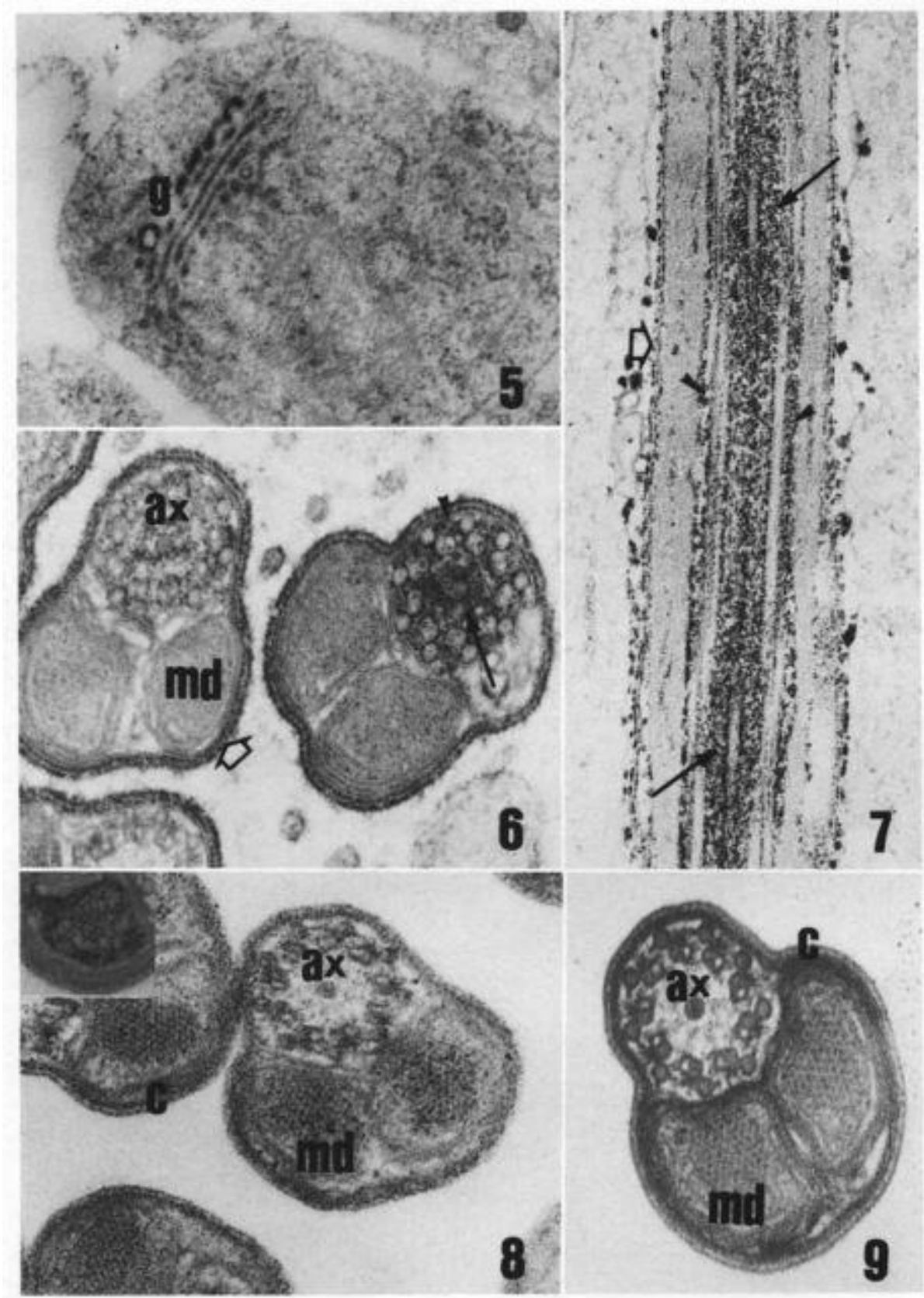

FIG. 5, Thin section of B-glycerophosphate incubated spermatid. Flagellar region showing reaction product in cisternae of Golgi complex (g). × 52,200. FxG. 6, Thin section of cytidine-5-monophosphateincubated spermatozoa. Cross-section of flagella showing reaction product in radial spokes (arrow) between central rod and 9 microtubule doublets, and in electron-dense fibres (arrowhead) between accessory microtubules of axoneme (ax). Coat (open arrow) is also acid phosphatase reactive. $\times 90,000$. FIG. 7. Longitudinal section of flagellum of 13-glycerophosphate-incubated spermatozoon. Reaction product is seen in radial spokes (arrow) near the central rod and electron-dense fibres (arrowhead) near accessory microtubules. Cell surface (open arrow) is also acid phosphatase reactive, x 50,400. FIG. 8. Thin sections of cytidine-5-monophosphate-incubated spermatozoa. Cross-section of flagellar showing reaction product in mitochondrial derivatives $(\mathrm{md}) . \mathrm{c}=$ coat. $\times 90,000$. Inset shows acid phosphatase activity in paracrystalline matrix. $\times 81,000$. FIG. 9. Spermatozoon treated with an acid phosphatase medium to which $10 \mathrm{mM}$ sodium fluoride was added. Axoneme (ax), mitochondrial derivative (md), and coat (c) were non-reactive for acid phosphatase, $x$ 90,000. 

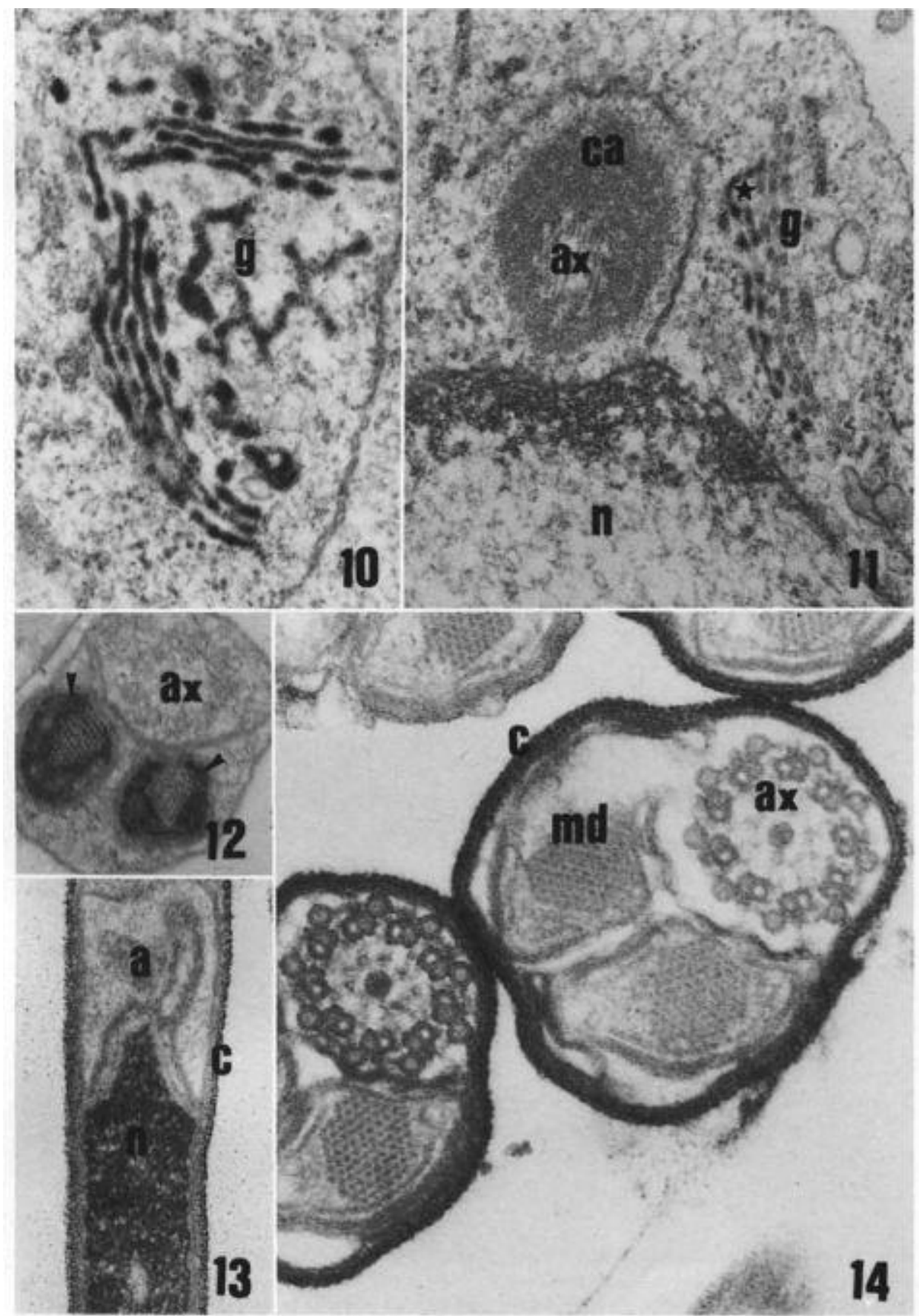

FIGs 10--14. Localization of thiamine pyrophosphatase in spermatids and spermatozoa. FiGs 10, 11. Reaction product is associated with several cisternae of Golgi complex (g), especially those located in cis region (star in Fig. 12). ax = axonema; ca = centriole adjunct; $n=$ nucleus. Figure 10: $\times$ 54,000; Fig. 11: $\times$ 49,500. FIG. 12. Cross-section through flagellum showing reaction product in layer of amorphous material (arrowhead) of mitochondrial derivatives, ax = axoneme, $x 68,400$. FIG. 13. Longitudinal section through head region of a spermatid in final stage of differentiation. Coat $(c)$ in this region shows reaction for thiamine pyrophosphatase, $\mathrm{a}=$ acrosome; $\mathrm{n}=$ nucleus. $x 58,500$. FIG. 14 . Reaction product is present in coat (c) of spermatozoa surface, ax = axoneme- $\mathrm{md}=$ mitochondrial derivative, $\mathrm{x} 148,000$. 


\section{DISCUSSION}

Our observations show that in early spermatids, acid phosphatase can be detected cytochemically mainly in the trans-most portion of the Golgi complex. The detection of enzyme reaction product in the spermatid Golgi complex suggests that this membrane system is involved in the segregation of hydrolases required for the controlled hydrolysis of some cell components or for the utilization of this enzyme in other metabolic processes (Anderson et al., 1968).

Our observations on thiamine pyrophosphatase show that although reaction product can be detected in both the cis and trans sacculae of the Golgi complex, it preferentially occurs in association with the cis-most portion. However, early spermatids of the rat have shown that reaction product, indicative of thiamine pyrophosphatase, occurs in the trans-sacculae (Hermo et al., 1980; Clermont et al., 1981), as seen in most other cells (Rambourg et al., 1987; Rambourg and Clermont, 1990), although it can occasionally be observed in the trans-Golgi network (Griffiths et al., 1989).

During the early phases of insect spermiogenesis, the Golgi complex contributes materials to the developing hydrolase-rich acrosomic system (Phillips, 1970; Baccetti, 1972; Bao et al., 1989; Ndiaye and Mattei, 1992). In this paper we have shown the presence of acid phosphatase activity in the anterior acrosomal region of the spermatozoon. But it is restricted to a membrane complex involved in the appearance of a distinct compartment in the acrosome of the spermatozoon. Previous studies have shown that acid phosphatase is not present in the acrosome (Anderson, 1968; Souza and Azevedo, 1986; Bao et al., 1989). According to these authors, this enzyme is stored in an inactive state and becomes active only at fertilization, when it participates in the dissolution of the oocyte coat, allowing the penetration of the spermatozoon. Acid phosphatase activity was found in ionophore-treated spermatozoa suspensions, suggesting that acid phosphatase originates from the spermatozoon acrosome, during the acrosomal reaction process (Souza et al., 1988).

In spermatids, most of the endoplasmic reticulum cisternae displayed glucose-6phosphatase activity. One of the features observed in the present study was the presence of the glucose-6-phosphatase reactivity in cisternae located in the transition zone between the endoplasmic reticulum and the Golgi complex. The present observations confirm a close topographical association of endoplasmic reticulum cisternae with the cisface of the Golgi complex in germinal cells (Sandoz, 1970; Hermo et al., 1980; ThorneTjomsland et al., 1991) and other cell types (Farquhar, 1985; Queiroz et al., 1991). 


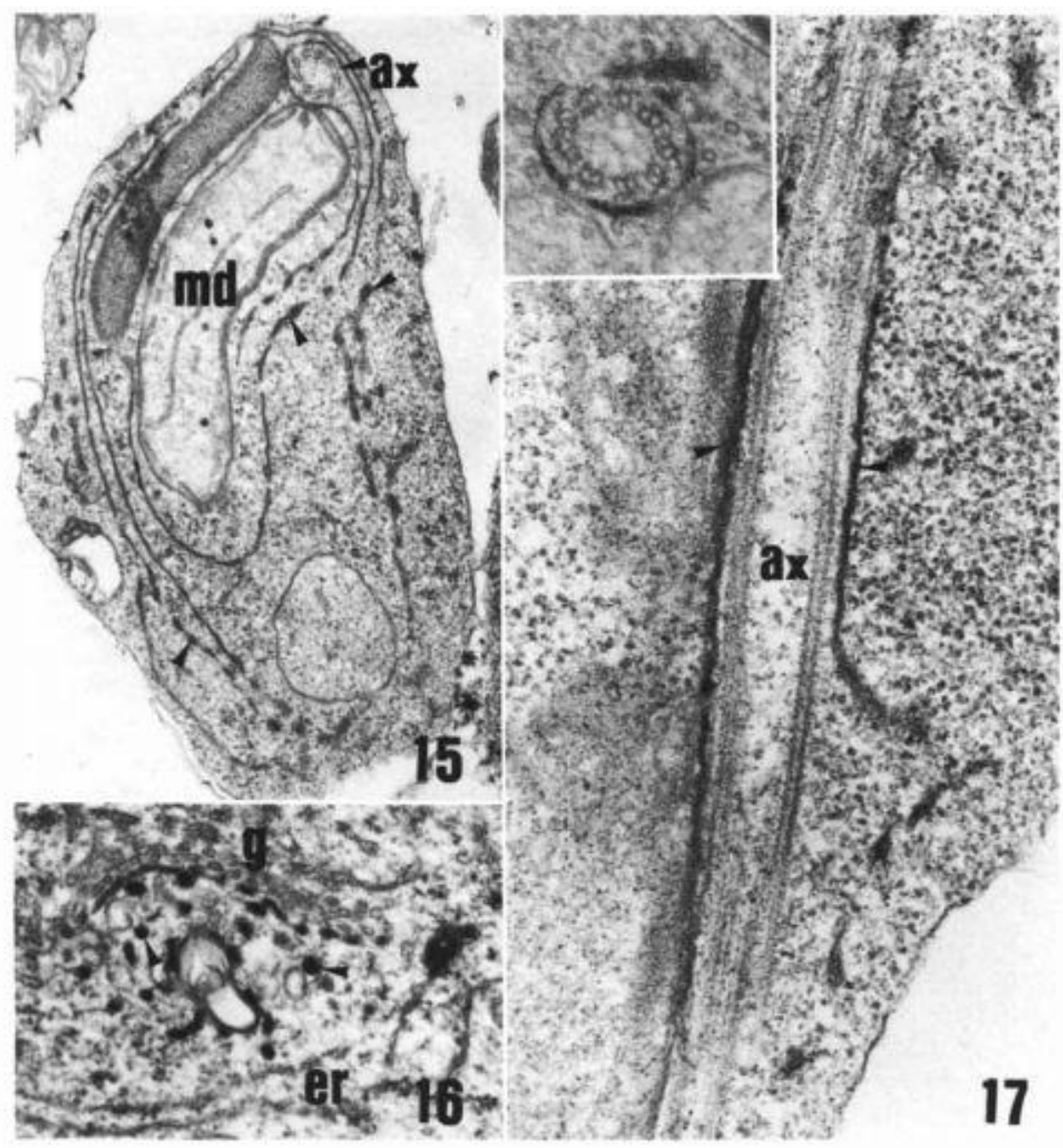

F16s 15-17. Localization of glucose'-6-phosphatase in the spermatids. FIG. 15. Section through flagellar region. Reaction product can be seen in association with profiles of endoplasmic reticulum (arrowhead). $\mathrm{ax}=$ axoneme; $\mathrm{md}=$ mitochondrial derivative, $\mathrm{x} 24,300$. FIG. 16. A spotty reaction is observed in cisternae (arrowhead) located in transition zone between endoplasmic reticulum (er) and Golgi complex (g). $\times 30,600$. FIG. 17. Reaction product can be seen in cisternae (arrowhead) that surround axoneme (ax). $x 47,700$. Inset shows a spotty reaction in cisternae that surround axoneme in a cross-section. $\times$ 81,000 .

The regions of the axoneme where acid phosphatase activity was detected coincide with known descriptions for the spermatozoa of a few insects (Anderson et al., 1968; Bigliardi et al., 1970; Baccetti, 1972; Baccetti et al., 1971, 1973b; Beaulaton and PerrinWaldemer, 1973; Bao and Dolder, 1990; Bao, 1991). This enzymatic activity begins only after the axoneme has acquired all of its microtubules and interconnecting fibres, and is fully equipped for movement. Acid phosphatase is apparently involved in the metabolism of phosphates, important for the flagellar motility. It is interesting to note that a heterogeneity in intensity of reaction was observed. Our suggestion concerning this difference is due to the fact that the axoneme may show different functional activity, and consequently changes occur in the 
metabolism of phosphates. This heterogeneity of reaction to the acid phosphatase activity was previously observed in axoneme of Ceratitis capitata sperm (Bao and Dolder, 1990).

Our observations show the presence of acid phosphatase activity in the mitochondrial derivatives, suggesting that hydrolases may function in the metabolism of this organelle. However, in spermatids, in the amorphous material that surrounds the paracrystalline structure, a thiamine pyrophosphatase activity was also observed, suggesting that this enzyme participates in the differentiation of the mitochondrial derivatives. These heterogeneities in reactions to the hydrolases may be due to the different enzymatic activity in the metabolism of the mitochondrial derivative. There are no previous reports on the presence of thiamine pyrophosphatase in the mitochondrial derivative. The existence of such intramitochondrial phosphatase activity has been described previously in sea urchin and sea star spermatozoa (Anderson, 1968; Souza and Azevedo, 1986).

Ultrastructural studies have shown that the plasma membrane remodelling occurs during differentiation of spermatid in C. quinquefasciatus with the appearance of a thick surface coat in its outer surface (Bao and de Souza, 1992, 1993). This remodelling during spermatid differentiation in insects is characterized by the development of an almost complete new membrane and involves the participation of the Golgi complex (Baccetti, 1975, 1977). Acid phosphatase, thiamine pyrophosphatase, and glucose-6-phosphatase seem to be enzyme markers of the spermatozoon cell surface in this mosquito. The endoplasmic reticulum and Golgi complex seem to be involved in the formation of the surface coat. These enzymes may also be involved in the chemical changes underlying contact and fragmentation of the membranes during the fertilization process.

Acknowledgements -- We thank Dr R. L. de Oliveira for supplying the mosquitoes and Dr E. W. Kitajima of University of Brazflia for the use of the Electron Microscope Laboratory. This work was supported by Financiadora de Estudos e Projetos (FINEP), Conselho Nacional de Desenvolvimento Cientifico e Tecnol6gico (CNPq), and Coordenat; $\sim$ io de Aperfei :oamento de Pessoal de Nivel Superior (CAPES).

\section{REFERENCES}

ANDERSON, W. A. 1968. Cytochemistry of sea gametes. III. Acid and alkaline phosphatase activity of spermatozoa and fertilization. J. Ulstrastruct. Res. 25: 1-14. 
ANDERSON, W. A. and P. PERSONNE. 1970, Recent cytoehemical studies on spermatozoa of some invertebrate and vertebrate species, pp. 431-50. In B. BACCETn (ed.) Comparative Spermatology. Accademia Nazional dei Lincei, Rome.

ANDERSON, W. A., P. PERSONNE and J. ANDRE. 1968. Chemical compartmentalization in Helix spermatozoa. J. Microsc. 7: 367-90.

ANGERMULLER, S. L. and D. H. FAHIML 1984. A new cerium-based method for cytochemical localization of thiaminepyrophosphatase in the Golgi complex of rat hepatocytes.

Histoehemistry 80: 107-11.

BACCETTI, B. 1972. Insect sperm cells. Adv. Insect Physiol. 9: 315-97.

BACCETTI, B. 1975. The role of the Golgi complex during spermiogenesis. Curt. Top. Dev. Biol. 10: $103-22$.

BACCETTI , B. 1977. Unusual features of insect spermatogenesis, pp. 580--87. In B. R. BmNKLEV and K. R. PORTER (eds) International Cell Biology. Rockefeller University Press, New York.

BACCETTI , B. and B. A. AFZELIUS (eds) 1976. The Biology of the Sperm Cell. Karger Basel, New York.

BACCETTI, B., F. BERNINE, E. BIGLIARDI, A. G. BURRINI, R. DALLAI, F. GIUSTI, M. MAZZINI, V. PALLINI, T. RENIERI, F. ROSATI, G. SELMI and M, VEONI. 1973a. Motility patterns in sperms with different tail structure, pp. 141-50. In B. A. AFZELIUS (ed.) The Functional Anatomy of the Spermatozoon. Pergamon Press, Oxford.

BACCETTI, B., E. BIGLIARDI, A. G. BURRINI and F. ROSATI. 1971. Histochemical observations on the insect sperm cell by electron microscope. J. Ultrastruct. Res. 37: 248--49.

BACCETTI, B., A. G. BURRINI, R. DALLAI, F. GIUSTI, M. MAZZINI, T. BENIERI, F. ROSATI and G. SELMI. 1973b. Structure and function in the spermatozoon of Tenebrio molitor: the spermatozoon of Arthropoda XX. J. Mechanochem. Cell Motility 2: 149-61.

BAD, S. N. 1991. Morphogenesis of the flagellum in the spermatids of Coelomera lanio (Coleoptera, Chrysomelidae): ultrastructural and cytochemical studies. Cytobios 66: 157-67.

BAD, S. N. and H. DOLDER. 1990. Ultrastructural localization of acid phosphatase in spermatic cells of Ceratitis capitata (Diptera). Histochemistry 93: 439--42.

BAD, S. N. and W. DE SOUZA. 1992. Distribution of intramembranous particles and filipin-sterol complexes in the spermatid and spermatozoon of Culex quinquefasciatus (Culicidae). Biol. Cell 75: 37-44.

BAD, S. N. and W. DE SOUZA. 1993. Ultrastructural and cytochemical studies of the spermatid and spermatozoon of Culex quinquefasciatus (Culicidae). J. Submicrosc. Cytol. Pathol. 25: 21322.

BÁO, S. N., I. QUAGIO-GRASSIOTTO and H. DOLDER. 1989. Acrosome formation in Ceratitis capitata (Diptera, Tephritidae). Cytobios 53: 93-100. 
BÁO, S. N., U. LINS, M. FARINA and W. DE SOUZA. 1992. Mitochondrial derivatives of Culex quinquefasciatus (Culicidae) spermatozoon: some new aspects evidenced by cytochemistry and image processing. J. Struct. Biol. 109: 46-51.

BEAULATON, J. and C. PERRIN-WALDEMAR. 1973. Localisation ultrastructural d'une activit6 phosphatasique acide dans les spermatides et les spermatozoides de Drosophila melanogaster. C. R. Acad. Sci. (Paris) 276: 2277-80.

BIGLIARDI, E., I. BACCETTI, A. G. BURR1NI and V. PALLINI. 1970. The spermatozoon of Arthropoda. XIII The distribution of some enzymes in the insect sperm tail, pp. 451-63. In B. BACCETTI (ed.) Comparative Spermatology. Accademia Nazional dei Lincei, Rome.

CIBERT, C. 1985. Identification of an ATPase activity associated with the high molecular weight proteins of the human spermatozoon axonemes. Biol. Cell 55: 63-70.

CLERMONT, Y., M. LALLI and A. RAMBOURG. 1981. Ultrastructural localization of nicotinamide adenine dinucleotide phosphatase (NADPase), thiamine pyrophosphatase (TPPase), and cytidine monophosphatase (CMPase) in the Golgi apparatus of early spermatids of the rat. Anat. Rec. 201: 613-22.

CURTIS, S., O. B. BENNER and G. MUSIL. 1989. Ultrastructure of the spermatozoon of Megaselia scalaris Loew (Diptera : Brachycera : Cyclorrhapha : Phoridea : Phoridae). J. Morphol. 200: 47-61.

FARQUHAR, M. G. 1985. Progress in unraveling pathways of Golgi traffic. Ann. Rev. Cell Biol. 1: 447-88.

FAWCETI, D. W. 1975, The mammalian spermatozoon. Dev. Biol. 44: 394-436.

GORDON, M. 1973. Localization of phosphatase activity on the membranes of the mammalian sperm head. J. Exp. Zool. 185: 111-20.

GRIFFITHS, G., S. D. FULLER, R. BACK, M. HOLLINSHEAD, S, PFEIFFER and K. SIMONS. 1989. The dynamic nature of the Golgi complex. J. Cell Biol. 108: 257-77.

HERMO, L., A, RAMBOURG and Y. CLERMONT. 1980. Three-dimensional architecture of the cortical region of the Golgi apparatus in rat spermatids. Amer. J. Anat. 157: 357-73.

NDIAYE, M. and X. MATTEL. 1992. Particularity of acrosome formation during spermiogenesis in two mosquitoes: Toxorhynchites brevipalpis and Anopheles gambiae. J. Submicrosc. Cytol. Pathol. 24: 269-72.

PHILLIPS, D. M. 1970. Insect sperm: their structure and morphogenesis. J. Cell Biol. 44: 243-77.

PINo, R. M., L. C. PINO and P. W. BANKSTON. 1981. The relationships between the Golgi apparatus, GERL, and lysosomes of fetal rat live Kupffer cells examined by ultrastructural phosphatase cytochemistry. J. Histochem. Cytochem. 29: 1061-70.

QUEIROZ, R. C. B., L. M. SILVA SANTOS, M. BENCHIMOL and W. DE SOUZA. 1991. Cytochemical localization of enzyme markers in Tritrichomonasfoetus. Parasitol. Res. 77: 561-66. 
RAMBOURG, A. and Y. CLERMONT. 1990. Three-dimensional electron microscopy: structure of the Golgi apparatus. Eur. J. Cell Biol. 51: 185-200.

RAMBOURG, A., Y. CLERMONT, L. HERMO and D. SEGRETAIN. 1987. Three-dimensional structure of the Golgi apparatus of non ciliated epithelial cells of the ductuli efferents in rats: an electron microscope stereoscopic study. Biol. Cell 60: 103-16.

ROBINSON, J. M. and M. J. KARNOVSKY. 1983. Ultrastructural localization of several phosphatases with cerium. J. Histochem. Cytochem. 31: 1197-208.

SANDOZ, D. 1970. Evolution des ultrastructures au cours de la formation de l'acrosome de spermatozoide chez la souris. J. Microsc. (Paris) 9: 535-58.

SOUZA, M. and C. AZEVEDO. 1986. Cytochemical study on the spermatozoon and at early fertilization in Marthasterias glacialis (Echinodermata, Asteroidea). Biol. Cell 56: 79-84.

SOUZA, M., P. MORADAS FERREIRA, A. AMORIN and C. AZEVEDO. 1988. Starfish acrosomal acid phosphatase: a cytochemical and biochemical study. Biol. Cell. 63: 101--4.

THORNE-TJOMSLAND, G., Y. CLERMONT and L. HERMO. 1988. Contribution of the Golgi apparatus components to the formation of the acrosomic system and chromatoid body in rat spermatids. Anat. Rec. 221: 591-98.

THORNE-TJOMSLAND, G., Y. CLERMONT and X. TANG. 1991. Glucose-6-phosphatase activity of endoplasmic reticulum and Golgi apparatus in spermatocytes and spermatids of the rat: an electron microscopic cytochemical study. Biol. Cell 71: 33--41.

YASUZUMI, G., S. YAMAGUCHI, Y. TAKAHASH1, Y. NISHIMURA and N. YAMAGISHI. 1973. The structural and cytochemical bases for vertebrate and invertebrate sperm motility, pp. 151-59. In B. A. AFZELIUS (ed.) The Functional Anatomy of the Spermatozoon. Pergamon Press, Oxford. 